Viktorija Tyshhenko,

Doctor of Economics, Associate Professor, Research Associate, Research Centre for Industrial Development Problems of NAS of Ukraine (Kharkiv, Ukraine); Nadiia Bielikova,

Doctor of Economics, Associate Professor, Scientific Secretary, Research Centre for Industrial Development Problems of NAS of Ukraine (Kharkiv, Ukraine); Viktorija Ostapenko, $P h D$ in Economic Sciences, Lecturer of the Department of management of financial services, Simon Kusnets Kharkiv National University of Economics (Kharkiv, Ukraine)

\title{
COGNITIVE MODELLING IN PROCESS MANAGEMENT OF PUBLIC-PRIVATE PARTNERSHIPS INTENSIFYING IN UKRAINE
}

\begin{abstract}
The article presents the author's view on the cognitive modelling processes application to enhance the management of public-private partnerships (PPPs) in the regions of Ukraine. The authors have formed a factors system for public and private partners, that have a positive or negative effect on the PPPs activation (target concept "Investments"). It was proposed to use cognitive maps to investigate causal relationships among factors. It was developed the cognitive model concepts influence set of the target concept "Investments" and it was made its static analysis (it was identified concepts that carry the greatest dissonance of the system).

Keywords: public-private partnership, cognitive modelling, symbolic directed graph, consonance, dissonance, economic reforms.
\end{abstract}

DOI: 10.21272/mmi.2017.3-27

Problem statement. Economic reforms in Ukraine have more rapid pace since 2014. Directions and areas of reforms are wide. This fact can be seen in government program documents, such as Sustainable Development Strategy of Ukraine - 2020 [1], Plan of legislative support of the reforms [2], The Cabinet of Ministers Program activities [3] and others. The priority of economic development incentives is presented in all this documents. In particular, public-private partnerships are considered as an effective mechanism for accelerating of economic growth in the regions of the country. Under the current economic conditions the country lacks its own funds to finance socially important projects and services in the whole state and regions. It forced these projects to involve businesses, so urgent the problem of interaction between the state and the private partner is. The situation in the sphere of interaction between the state and business is characterized, on the one hand, by the recognition of government officials, business sector and the academic community of high relevance to stimulate intersectional cooperation, the emergence of successful management models and the positive results of the PPPs, strengthening of institutional preconditions for efficient management of such an interaction, on the other hand, there is no consistency in addressing emerging issues, not clearly defined imperatives and vector control of these changes in the context of stimulating the socio-economic development. One of the most promising and most convenient options for such cooperation is the public-private partnerships (PPPs). Despite the recognition of this form of cooperation as one of the major tools for improving national competitiveness, implementation of PPPs in Ukrainian practice is extremely slow. The problem in management process of both partners interaction is referred to poorly structured systems. The modelling of such systems and their management using of traditional approaches based on analytical description or statistical observation are difficult processes. To assess the effects of economy management system of PPPs influences it is necessary to encourage the use of partnerships at regional and national levels, and cognitive modelling can be an effective tool. Application of this tool allows 
identifying and analyzing the main causal relationships in system components interaction between public and private sectors that are integrated into the regional socio-economic system identifying areas of control actions that are aimed at stimulating the activation of interaction.

Analysis of recent researches and publications. Cognitive modelling problem was examined by a lot of famous scientists, such as R. Axelrod [4], A. Bakurova [5], E. Bykovskaya [6], I. Dolzhanskiy [7], B. Kosko [8], O. Kolodiziev [9], D. Lagerev [10], V. Maksimov [11,12], N. Paklin [13], W. Sylov [14], V. Shemayev $[15,16]$. The following aspects of cognitive modelling are not worked out; in particular, methods for structuring situations that build cognitive maps are based on the work of the experts, explain the methods and results of adjustment models for situation analysis. The fundamental theoretical and practical aspects of partnership between the state and the private sector (PPPs) are considered in the works such scientists as O. Golovinov [17], M. Gerrard [18], I. Zapatrina [19], L. Fedulova [20], P. Shylepnytskyi [21]. But scientists did not pay enough attention to studying the factors that contribute to the stimulation of PPPs.

The aim of the article is to determine the factors that contribute to the stimulation of PPPs suggestion using cognitive modelling.

Results of the research. The principal difference of PPPs is the subjects who participate in the project. In the study [22] it was used the subjective approach and defined the essence of public and private partners. To determine the factors that contribute to the stimulation of PPPs suggest using cognitive modelling (Figure 1).

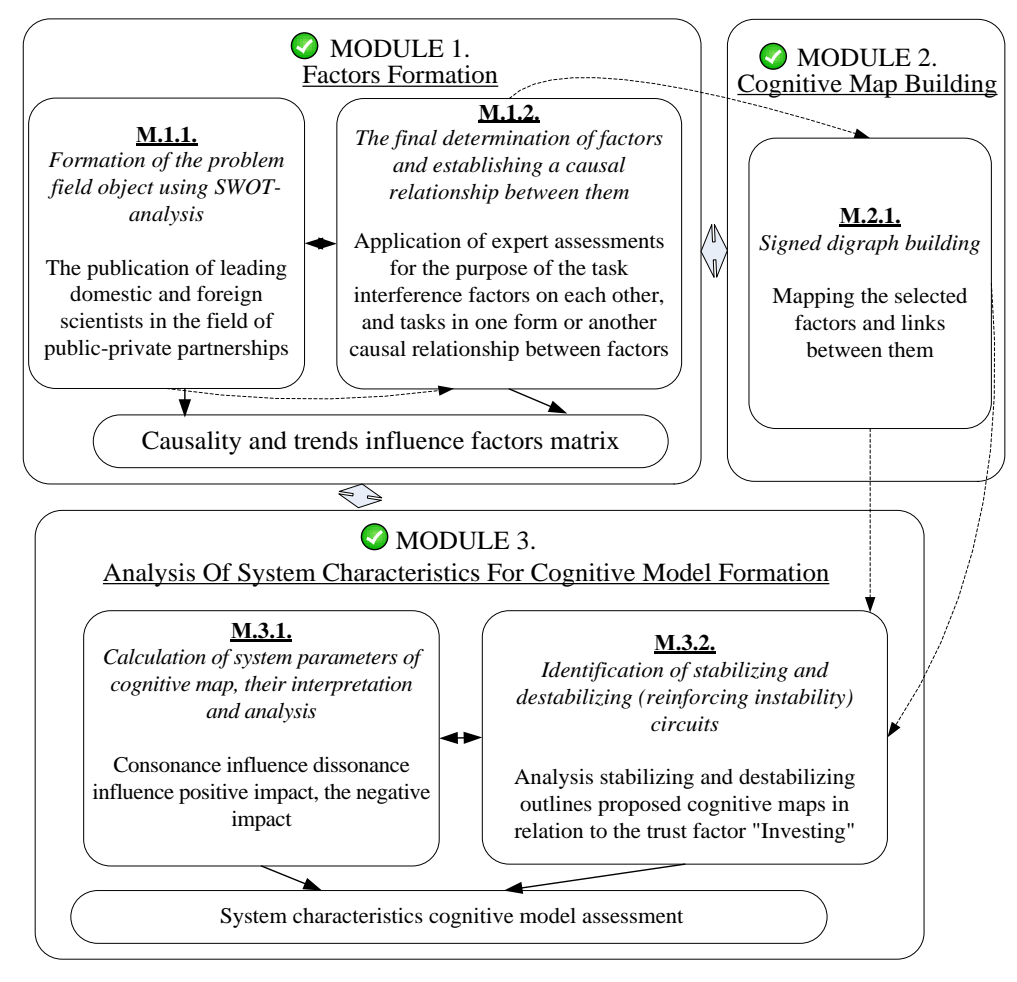

Figure 1 - The general scheme of theoretical and methodological approach to study the factors that contribute to the stimulation of PPPs (prepared by the authors) 
В.Ф. Тищенко, Н.В.Белікова, В.М. Остапенко. Когнітивне моделювання при управлінні процесами активізації публічно-приватного партнерства в Україні

Positive aspects of the chosen research methods are shown in Table 1.

Table 1 - Positive aspects of cognitive modelling processes to PPPs stimulation (generalized by $[8,14]$ )

\begin{tabular}{|c|c|c|}
\hline Positive aspects & Characteristic & Implementation details in PPPs system \\
\hline $\begin{array}{l}\text { Multiaspects and } \\
\text { interconnectedness } \\
\text { of phenomena and } \\
\text { processes } \\
\text { consideration } \\
\end{array}$ & $\begin{array}{c}\text { Introduction of cognitive maps in the form of graphs allows } \\
\text { to predict an indirect link among impacts and reflects the } \\
\text { causal relationships among them }\end{array}$ & $\begin{array}{c}\text { The need to consider many factors and targets with } \\
\text { complex hierarchical structure of the relationship, } \\
\text { and often conflicting needs to take account of all } \\
\text { the relationships among them }\end{array}$ \\
\hline $\begin{array}{l}\text { The visual image of } \\
\text { the subject area that } \\
\text { is simulated }\end{array}$ & $\begin{array}{l}\text { Represents only basic (small amount) factors and } \\
\text { relationships. Displays only the main laws and regularities. } \\
\text { Constructability, visibility and relative ease the } \\
\text { interpretation on the basis of causality (relations) among } \\
\text { concepts }\end{array}$ & $\begin{array}{c}\text { Illustration of causal relationships among factors of } \\
\text { internal and external environment of PPPs allows } \\
\text { to further consider subjective opinion makers } \\
\text { decision }\end{array}$ \\
\hline $\begin{array}{l}\text { Efficiency in terms of } \\
\text { incomplete } \\
\text { information }\end{array}$ & $\begin{array}{l}\text { Unlike simulation modelling approaches that focus on } \\
\text { quantitative objective assessments, traditional methods of } \\
\text { decision theory, based on the methods of selecting the } \\
\text { best alternative from a set of clearly defined alternatives } \\
\text { and scenario analysis techniques, cognitive maps are used } \\
\text { in conditions of uncertainty and inability decision, } \\
\text { management decisions are only based on quantitative } \\
\text { assessments because some details of the situation } \\
\text { (mentioned factors, the degree of influence among them) } \\
\text { are not quantitative and qualitative }\end{array}$ & $\begin{array}{l}\text { The development of PPPs is characterized by the } \\
\text { inability to describe the unambiguous analytical or } \\
\text { statistical observation dependencies between input } \\
\text { and output parameters of the system. } \\
\text { Often we have to resort to subjective models based } \\
\text { on expert information processes involving logic of } \\
\text { "common sense", intuition and heuristics }\end{array}$ \\
\hline $\begin{array}{l}\text { Increase quality of } \\
\text { management } \\
\text { solutions }\end{array}$ & $\begin{array}{c}\text { The integration scenario and competency approach } \\
\text { provide a view of all important aspects of the research } \\
\text { object or problem situation with its presence and anticipate } \\
\text { all scenarios }\end{array}$ & $\begin{array}{c}\text { Lack of information about the dynamic processes } \\
\text { of PPPs offset system formation of causal } \\
\text { relationships between factors of influence allows to } \\
\text { develop different kinds of scenarios }\end{array}$ \\
\hline $\begin{array}{l}\text { Displaying strait } \\
\text { relations between } \\
\text { factors }\end{array}$ & $\begin{array}{l}\text { Is implemented through the basic system performance, } \\
\text { which is determined by mutual consonance, dissonance, } \\
\text { positive and negative effects of concepts on each other }\end{array}$ & $\begin{array}{c}\text { Constructability, visibility and relative ease of } \\
\text { interpretation on the basis of causality (relations) } \\
\text { among concepts }\end{array}$ \\
\hline
\end{tabular}

Cognitive model of causal relationships among factors that contribute to the promotion of PPPs is presented as a formal dependence [6]:

$$
\mathrm{K}_{P P P}(E, F) \text {, }
$$

where $E\left(E_{1}, E_{2}\right)$ is a directed graph (a cognitive map), which vertices correspond to elements of the set $E_{1}$ (factors):

$$
\begin{aligned}
& E_{1}=\left\{e_{1}^{i} \mid e_{1}^{j} \in E_{1}\right\}, i=\overline{1, n}, \mathrm{j}=\overline{1, m} \\
& E_{2}=\left\{e_{2}^{i} \mid e_{2}^{j} \in E_{2}\right\}, i=\overline{1, n}, \mathrm{j}=\overline{1, m}
\end{aligned}
$$

The impact can be positive, negative or non-existent. Functional transformation curves:

$$
F=F\left(E_{1}, E_{2}\right)
$$

Building of the cognitive model is based on a cognitive map which is designed for visual presentation of basic laws and patterns as a sign-oriented graph in following [16]: 
1) peaks in cognitive maps meet basic factors influencing the PPPs activation;

2) curves determine causal relationships among factors describing the propagation effects of particular factors on the other ones. There are two types of causation in the cognitive model: positive and negative. If relationship among the factors is positive it is shown as "+" sign on the map, if there is a negative correlation, it is shown as a "-" sign on the map.

MODULE 1: the system factors were formed and distinguished into two general groups by views of scientists who have studied PPPs [17-21] (Table 2). Formation of the problem field object using SWOTanalysis is presented in the study [23].

Table 2 - System factors that contribute to the promotion of PPPs (prepared by the authors)

\begin{tabular}{|c|c|c|c|}
\hline Symbol & Group & Factor & Explanation \\
\hline$E_{1}$ & \multirow{8}{*}{ 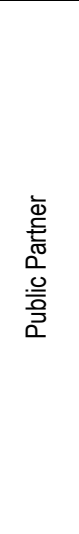 } & Legislation quality & $\begin{array}{l}\text { Positive or negative changes in the law regarding the } \\
\text { scope of implementation of PPPs }\end{array}$ \\
\hline$E_{2}$ & & $\begin{array}{l}\text { The share of government spending } \\
\text { on infrastructure operation }\end{array}$ & $\begin{array}{l}\text { Spending on public sector infrastructure operation in the } \\
\text { PPPs implementation }\end{array}$ \\
\hline$E_{3}$ & & The economic security of the region & $\begin{array}{l}\text { Measures and the ability of the economy to maintain the } \\
\text { implementation of national and state interests }\end{array}$ \\
\hline $\mathrm{E}_{4}$ & & The quality of public services & $\begin{array}{l}\text { Services, which are provided at public partner in the } \\
\text { implementation of PPPs }\end{array}$ \\
\hline$E_{5}$ & & Labour market & $\begin{array}{c}\text { Increase or decrease of the number of jobs depending on } \\
\text { the PPPs development in the region }\end{array}$ \\
\hline$E_{6}$ & & $\begin{array}{l}\text { Infrastructure and institutional } \\
\text { environment }\end{array}$ & $\begin{array}{l}\text { The development of infrastructure in the region and its } \\
\text { institutional environment }\end{array}$ \\
\hline$E_{7}$ & & PPPs risks & $\begin{array}{l}\text { Increase or decrease of various types of risks that arise } \\
\text { during the implementation of PPPs programs and projects }\end{array}$ \\
\hline $\mathrm{E}_{8}$ & & Bureaucracy and corruption & $\begin{array}{l}\text { Bureaucratic barriers between public and private partners } \\
\text { in the PPPs implementation }\end{array}$ \\
\hline$E_{9}$ & \multirow{6}{*}{ 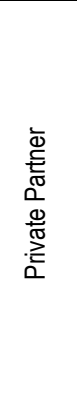 } & Innovations & $\begin{array}{c}\text { Involvement of modern highly efficient, resource-saving } \\
\text { programs and new technologies in the PPPs projects } \\
\text { implementation }\end{array}$ \\
\hline$E_{10}$ & & Competitiveness & The ability to implement large scale PPPs projects \\
\hline$E_{11}$ & & $\begin{array}{l}\text { The relative cost of services for } \\
\text { consumers }\end{array}$ & Cost of services (works, products) and costs under PPPs \\
\hline$E_{12}$ & & $\begin{array}{l}\text { The economic security of private } \\
\text { business }\end{array}$ & $\begin{array}{l}\text { Ensuring the security of private sector in the PPPs } \\
\text { implementation }\end{array}$ \\
\hline$E_{13}$ & & Business risk & $\begin{array}{l}\text { Increase or decrease of various types of risks that arise } \\
\text { during the PPPs programs and projects implementation }\end{array}$ \\
\hline $\mathrm{E}_{14}$ & & Investments & $\begin{array}{l}\text { The volume of attracted funds of private partner in the } \\
\text { PPPs mechanisms implementation }\end{array}$ \\
\hline
\end{tabular}

MODULE 2: definition of relationship of causality and direction of influence among selected factors are shown in the matrix (Table 3).

The relative trust factor "Investments" is presented in the form of cognitive maps (Figure 2), which is a sign graph. Sign graph includes the most important direct links. This graph is used for the qualitative evaluation of the impact of certain factors on the stability of the system (test vector). Peak of cognitive maps corresponds to the factors that determine the situation and oriented edges that are the causal relationships among them. The positive cycle is a positive feedback circuit, weight gain factor in the cycle leads to the further growth. The negative cycle prevents deviation from its original state, but instability is possible in the form of significant fluctuations in the cycle. It includes the most important links.

Table 3 - Causality and directions of factors matrix on the public-private partnerships revitalization 
В.Ф. Тищенко, Н.В.Белікова, В.М. Остапенко. Когнітивне моделювання при управлінні процесами активізації публічно-приватного партнерства в Україні

(prepared by the authors)

\begin{tabular}{|c|c|c|c|c|c|c|c|c|c|c|c|c|c|c|}
\hline \multirow{2}{*}{$\frac{\text { Group }}{\text { Factor }}$} & \multicolumn{7}{|c|}{ Public partner factors } & \multicolumn{7}{|c|}{ Private partner factors } \\
\hline & $\mathrm{E}_{1}$ & $\mathrm{E}_{2}$ & $E_{3}$ & $\mathrm{E}_{4}$ & $\mathrm{E}_{5}$ & $\mathrm{E}_{6}$ & $E_{7}$ & $\mathrm{E}_{8}$ & $\mathrm{E}_{9}$ & $\mathrm{E}_{10}$ & $\mathrm{E}_{11}$ & $E_{12}$ & $\mathrm{E}_{13}$ & $E_{14}$ \\
\hline \multicolumn{15}{|c|}{ Public partner factors } \\
\hline Legislation Quality $\left(\mathrm{E}_{1}\right)$ & & -1 & +1 & +1 & +1 & +1 & -1 & -1 & +1 & +1 & -1 & +1 & -1 & +1 \\
\hline $\begin{array}{l}\text { The share of government } \\
\text { spending on infrastructure } \\
\text { operation }\left(E_{2}\right)\end{array}$ & 0 & & +1 & +1 & 0 & +1 & +1 & 0 & +1 & +1 & -1 & +1 & -1 & 0 \\
\hline $\begin{array}{c}\text { The economic security of } \\
\text { the region }\left(E_{3}\right)\end{array}$ & 0 & 0 & & +1 & 0 & +1 & -1 & -1 & +1 & +1 & -1 & +1 & -1 & +1 \\
\hline $\begin{array}{l}\text { The quality of public } \\
\text { services }\left(E_{4}\right)\end{array}$ & 0 & 0 & 0 & & 0 & 0 & -1 & 0 & 0 & +1 & -1 & +1 & -1 & 0 \\
\hline Labour market $\left(E_{5}\right)$ & 0 & 0 & 0 & 0 & & 0 & 0 & 0 & -1 & 0 & +1 & 0 & +1 & 0 \\
\hline $\begin{array}{c}\text { Infrastructure and } \\
\text { institutional environment } \\
\left(E_{6}\right)\end{array}$ & 0 & 0 & +1 & 0 & +1 & & -1 & 0 & +1 & +1 & -1 & +1 & -1 & +1 \\
\hline PPPs Risks $\left(E_{7}\right)$ & 0 & 0 & 0 & 0 & 0 & 0 & & 0 & -1 & -1 & +1 & -1 & +1 & -1 \\
\hline $\begin{array}{c}\text { Bureaucracy and } \\
\text { corruption }\left(\mathrm{E}_{8}\right)\end{array}$ & -1 & 0 & 0 & 0 & 0 & 0 & +1 & & -1 & -1 & 0 & -1 & 0 & -1 \\
\hline \multicolumn{15}{|c|}{$\frac{1}{\text { Private partner factors }}$} \\
\hline Innovations $\left(\mathrm{E}_{9}\right)$ & 0 & 0 & 0 & +1 & 0 & 0 & 0 & 0 & & +1 & -1 & +1 & -1 & +1 \\
\hline Competitiveness $\left(E_{10}\right)$ & 0 & 0 & 0 & 0 & 0 & 0 & 0 & 0 & +1 & & 0 & +1 & -1 & +1 \\
\hline $\begin{array}{l}\text { The relative cost of } \\
\text { services for consumers } \\
\left(E_{11}\right)\end{array}$ & 0 & 0 & 0 & 0 & 0 & 0 & 0 & 0 & 0 & 0 & & -1 & +1 & -1 \\
\hline $\begin{array}{c}\text { The economic security of } \\
\text { private business }\left(E_{12}\right)\end{array}$ & 0 & 0 & 0 & 0 & 0 & 0 & -1 & 0 & 0 & 0 & 0 & & -1 & +1 \\
\hline Business risk $\left(E_{13}\right)$ & 0 & 0 & 0 & 0 & 0 & 0 & 0 & +1 & 0 & -1 & 0 & 0 & & -1 \\
\hline Investments $\left(\mathrm{E}_{14}\right)$ & 0 & -1 & 0 & +1 & 0 & 0 & -1 & 0 & +1 & +1 & 0 & 0 & 0 & \\
\hline
\end{tabular}

Note: "+" - Positive connections; "-" - Negative connections; 0 - Lack of connections

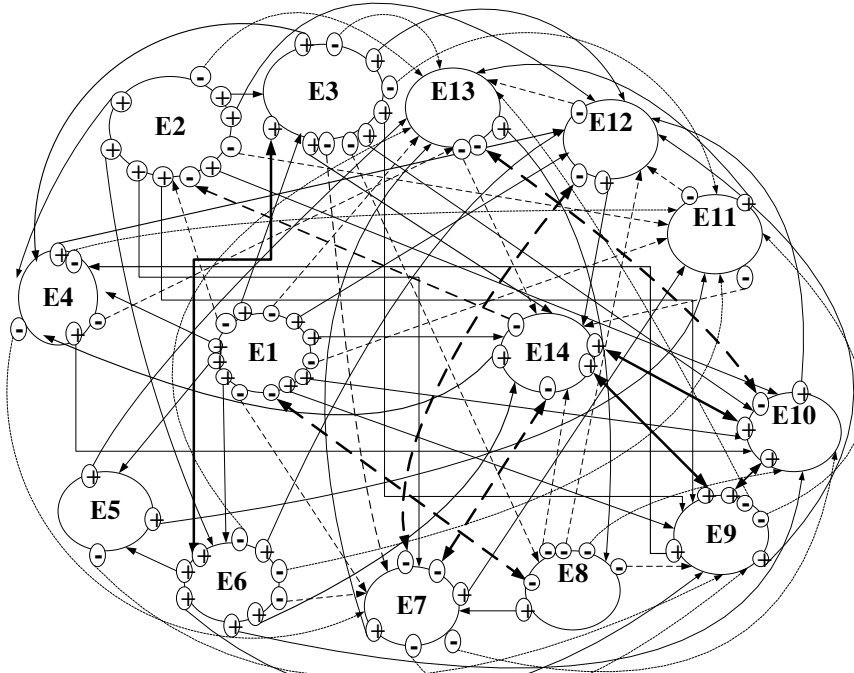

Figure 2 - The sign graph of cognitive maps for causal relationships among factors influencing incentives for public-private partnerships (prepared by the authors) 
It was identified the factors that affect the interaction stimulate public and private partners for PPPs. It was based on the installation of causal relationships among the set of factors using cognitive modeling:

1) factor "Innovation" $\left(E_{9}\right)$. An innovative way of development is a strategic factor that allows consolidating efforts through science, government and business to achieve improvement in engineering and technology, economic performance, social life, new quality of economic growth. Effective innovation is largely determined by forming support innovative initiatives that create attractive conditions for private investors, which is achieved through activation of interaction among public and private partners;

2) factor "Competitiveness" ( $\left.E_{10}\right)$ is an important factor affecting the development of the national economy and the economy as a whole. Implementation of competitive state projects on terms of partnership, on the one hand, is more attractive to private investors due to minimizing the risks of their implementation, and on the other hand, part business makes them more competitive thanks to the synergistic effect of joint efforts;

3) factors "PPPs Risks" $\left(E_{7}\right)$ and "Business Risk" ( $\left.E_{13}\right)$. Reduction of various types of risks that arise in the PPPs projects and programs implementation (both public partner and the private ones) has a positive impact on volume of attracted funds and increased PPPs;

4) factor "Infrastructure and institutional environment" $\left(E_{6}\right)$ is the basic tool that provides high-quality economic development. Infrastructure and institutional environment strengthen economic security of the country and facilitate the formation of an effective system of interaction among public and private partners;

5) factor "Quality of legislation" $\left(E_{1}\right)$ is characterized by the ability to reflect the objective laws of social relations, encourage positive trends in their changes. In the economic sphere the law is the main regulator of business, which aim is not only to protect it but also to promote development in various forms and manifestations, including public-private partnerships. PPPs develop actively in politically stable countries with effective legislative institutions that protect the rights of investors;

6) factor "Bureaucracy and corruption" $\left(E_{8}\right)$ is a factor that slows down the dynamic development of the economy. Improper performance of administrative procedures has a negative impact on the relations of public and private partners and leads to obstacles in business. Therefore, reduction of bureaucratic obstacles in the implementation of PPPs leads to reduction of risks to business and enhances PPPs;

7) factors "Economic security of the region" $\left(E_{3}\right)$ and "Economic security of private business" $\left(E_{12}\right)$. Socio-economic security of the country and its regions determines the stability of their development and holding back the threat of various political and economic risks that affect the social, innovation, investment and business climate. All of them influence the activation of partnership;

8) factor "Relative cost of services for consumers" ( $\left.E_{11}\right)$. World experience shows that the correlation between quality services and funds spent on it in the case of partnership usage is the best.

Another way of static analysis of cognitive model search is finding stabilizing and destabilizing (reinforcing instability) circuits. The greater number of simultaneous effects (in different ways) exists among the concepts, the stronger mutual influence is.

MODULE 3: there are the most important direct links among factors (those connections that are clear in the representation of experts) on the cognitive map (see Figure 2). But it also requires information on implicit (indirect) mutual influence factors for a full analysis of the causal effects of the set of factors on the activation process of PPPs. It was considered only the outlines, in which the target concept of cognitive model "Investments" is presented (Table 4).

Analysis of stabilizing and destabilizing outlines on cognitive maps showed that: all selected factors can be used as a target; it was allocated 34 cycles, amplified deviation and stabilized 31 cycles; it is possible to determine the direction of the impact of various factors influencing the activation process for PPPs on the basis of a signed digraph and causality matrix building. 
В.Ф. Тищенко, Н.В.Белікова, В.М. Остапенко. Когнітивне моделювання при управлінні процесами активізації публічно-приватного партнерства в Україні

Table 4 - The analysis of the sign count (compiled by the authors)

\begin{tabular}{|c|c|}
\hline \multicolumn{2}{|c|}{ Positive feedback (stabilizing contours) } \\
\hline$E_{14}-E_{4}-E_{12}-E_{14}$ & $E_{14}-E_{9}-E_{4}-E_{10}-E_{9}-E_{4}-E_{10}-E_{14}$ \\
\hline$E_{14}-E_{4}-E_{10}-E_{14}$ & $E_{14}-E_{9}-E_{4}-E_{10}-E_{9}-E_{4}-E_{10}-E_{12}-E_{14}$ \\
\hline$E_{14}-E_{4}-E_{10}-E_{12}-E_{14}$ & $E_{14}-E_{9}-E_{4}-E_{10}-E_{9}-E_{4}-E_{10}-E_{9}-E_{14}$ \\
\hline$E_{14}-E_{4}-E_{10}-E_{9}-E_{14}$ & $E_{14}-E_{9}-E_{4}-E_{10}-E_{9}-E_{4}-E_{10}-E_{9}-E_{12}-E_{14}$ \\
\hline$E_{14}-E_{4}-E_{10}-E_{9}-E_{12}-E_{14}$ & $E_{14}-E_{9}-E_{12}-E_{14}$ \\
\hline$E_{14}-E_{4}-E_{10}-E_{9}-E_{4}-E_{12}-E_{14}$ & $E_{14}-E_{9}-E_{10}-E_{14}$ \\
\hline$E_{14}-E_{4}-E_{10}-E_{9}-E_{4}-E_{10}-E_{14}$ & $E_{14}-E_{9}-E_{10}-E_{9}-E_{14}$ \\
\hline$E_{14}-E_{4}-E_{10}-E_{9}-E_{4}-E_{10}-E_{12}-E_{14}$ & $E_{14}-E_{9}-E_{10}-E_{12}-E_{14}$ \\
\hline$E_{14}-E_{4}-E_{10}-E_{9}-E_{4}-E_{10}-E_{9}-E_{14}$ & $E_{14}-E_{10}-E_{14}$ \\
\hline$E_{14}-E_{4}-E_{10}-E_{9}-E_{4}-E_{10}-E_{9}-E_{12}-E_{14}$ & $E_{14}-E_{10}-E_{12}-E_{14}$ \\
\hline$E_{14}-E_{9}-E_{14}$ & $E_{14}-E_{10}-E_{9}-E_{14}$ \\
\hline$E_{14}-E_{9}-E_{4}-E_{12}-E_{14}$ & $E_{14}-E_{10}-E_{9}-E_{12}-E_{14}$ \\
\hline$E_{14}-E_{9}-E_{4}-E_{10}-E_{14}$ & $E_{14}-E_{10}-E_{9}-E_{4}-E_{12}-E_{14}$ \\
\hline$E_{14}-E_{9}-E_{4}-E_{10}-E_{12}-E_{14}$ & $E_{14}-E_{10}-E_{9}-E_{4}-E_{10}-E_{14}$ \\
\hline$E_{14}-E_{9}-E_{4}-E_{10}-E_{9}-E_{14}$ & $E_{14}-E_{10}-E_{9}-E_{4}-E_{10}-E_{12}-E_{14}$ \\
\hline$E_{14}-E_{9}-E_{4}-E_{10}-E_{9}-E_{12}-E_{14}$ & $E_{14}-E_{10}-E_{9}-E_{4}-E_{10}-E_{9}-E_{14}$ \\
\hline$E_{14}-E_{9}-E_{4}-E_{10}-E_{9}-E_{4}-E_{12}-E_{14}$ & $E_{14}-E_{10}-E_{9}-E_{4}-E_{10}-E_{9}-E_{12}-E_{14}$ \\
\hline \multicolumn{2}{|c|}{ Negative feedback (destabilizing contours) } \\
\hline$E_{14}-E_{7}-E_{14}$ & $E_{14}-E_{7}-E_{12}-E_{7}-E_{9}-E_{11}-E_{14}$ \\
\hline$E_{14}-E_{7}-E_{9}-E_{13}-E_{14}$ & $E_{14}-E_{7}-E_{12}-E_{7}-E_{9}-E_{13}-E_{14}$ \\
\hline$E_{14}-E_{7}-E_{9}-E_{11}-E_{14}$ & $E_{14}-E_{7}-E_{12}-E_{7}-E_{10}-E_{13}-E_{14}$ \\
\hline$E_{14}-E_{7}-E_{9}-E_{11}-E_{12}-E_{13}-E_{14}$ & $E_{14}-E_{2}-E_{14}$ \\
\hline$E_{14}-E_{7}-E_{9}-E_{11}-E_{12}-E_{7}-E_{14}$ & $E_{14}-E_{2}-E_{11}-E_{14}$ \\
\hline$E_{14}-E_{7}-E_{9}-E_{11}-E_{12}-E_{7}-E_{12}-E_{13}-E_{14}$ & $E_{14}-E_{2}-E_{11}-E_{12}-E_{13}-E_{14}$ \\
\hline$E_{14}-E_{7}-E_{9}-E_{11}-E_{12}-E_{7}-E_{12}-E_{7}-E_{14}$ & $E_{14}-E_{2}-E_{11}-E_{12}-E_{7}-E_{14}$ \\
\hline$E_{14}-E_{7}-E_{9}-E_{11}-E_{12}-E_{7}-E_{9}-E_{11}-E_{12}-E_{13}-E_{14}$ & $E_{14}-E_{2}-E_{11}-E_{12}-E_{7}-E_{12}-E_{13}-E_{14}$ \\
\hline$E_{14}-E_{7}-E_{9}-E_{11}-E_{12}-E_{7}-E_{9}-E_{11}-E_{14}$ & $E_{14}-E_{2}-E_{11}-E_{12}-E_{7}-E_{12}-E_{7}-E_{14}$ \\
\hline$E_{14}-E_{7}-E_{9}-E_{11}-E_{12}-E_{7}-E_{9}-E_{13}-E_{14}$ & $E_{14}-E_{2}-E_{11}-E_{12}-E_{7}-E_{9}-E_{11}-E_{12}-E_{13}-E_{14}$ \\
\hline$E_{14}-E_{7}-E_{9}-E_{11}-E_{12}-E_{7}-E_{10}-E_{13}-E_{14}$ & $E_{14}-E_{2}-E_{11}-E_{12}-E_{7}-E_{12}-E_{7}-E_{9}-E_{11}-E_{12}-E_{13}-E_{14}$ \\
\hline$E_{14}-E_{7}-E_{12}-E_{13}-E_{14}$ & $E_{14}-E_{2}-E_{11}-E_{12}-E_{7}-E_{9}-E_{11}-E_{14}$ \\
\hline$E_{14}-E_{7}-E_{12}-E_{7}-E_{14}$ & $E_{14}-E_{2}-E_{11}-E_{12}-E_{7}-E_{9}-E_{13}-E_{14}$ \\
\hline$E_{14}-E_{7}-E_{12}-E_{7}-E_{12}-E_{13}-E_{14}$ & $E_{14}-E_{2}-E_{11}-E_{12}-E_{7}-E_{10}-E_{13}-E_{14}$ \\
\hline$E_{14}-E_{7}-E_{12}-E_{7}-E_{9}-E_{11}-E_{12}-E_{13}-E_{14}$ & $E_{14}-E_{2}-E_{13}-E_{14}$ \\
\hline & $E_{14}-E_{2}-E_{13}-E_{10}-E_{13}-E_{14}$ \\
\hline
\end{tabular}

It was determined the directions of development of the cognitive model (as detailed disclosure of meaningful indicators of the interaction between public and private sectors, identified functional relationships and causal relationships among factors of the system), which determines the possibility of setting up as a key element of the mechanism management decisions in the context of PPPs enhance the light of available empirical research base. It is possible to choose a suitable strategy for raising the activation of PPPs in Ukrainian regions based on the analysis of the relations of consonance, negative and positive impact. The developed model of specific numerical values will take into account the peculiarities of the system of PPPs and preferred directions of its development through ranking the degree of impact on the system as a whole.

The practical significance of the results of the study. It was determined that the proposed in the modelling tools control of the interaction between public and private sectors, which includes an assessment of regional economy effects of management actions, can be used by leaders of public organizations to improve the validity of the choice of strategies, formulation of objectives for sectorial cooperation and methods of achieving them.

Conclusions. Cognitive technology of analysis and modelling allows solving complex and uncertain 
situations quickly, comprehensively and systematically, describing and justifying on a qualitative level to offer solutions to problems in a given situation, taking into account various factors (concepts) of environment. It is possible to choose a suitable strategy for raising the activation of PPPs in Ukrainian regions based on these factors. Filling the specific content of the model will take into account the peculiarities of the system of PPPs and preferred directions of its development through ranking the degree of impact on the system as a whole. One of the areas for the further research can be a transition to sign directed graph in cognitive model for dynamic analysis of possible scenarios in time.

1. Про стратегію сталого розвитку «Україна - 2020»: Указ Президента України № 5/2015 від 12.01.2015 p. [Електронний ресурс]. - Режим доступу: http://zakon0.rada.gov.ua/laws/show/5/2015.

2. Про план законодавчого забезпечення реформ в Україні: Закон України № 509-19 від 04.06.2015 р. [Електронний ресурс]. - Режим доступу: http://zakon5.rada.gov.ua/laws/show/509-19.

3. Про програму діяльності Кабінету Міністрів України: Постанова Верховної Ради України № 1099-VIII від 19.04.2016 p. [Електронний ресурс]. - Режим доступу: http://zakon3.rada.gov.ua/laws/show/1099-19.

4. Axelrod R. The Structure of Decision: Cognitive Maps of Political Elites / R. Axelrod. - Princeton: University Press, 1976. - $153 \mathrm{p}$.

5. Бакурова А.В. Оцінка системних характеристик когнітивної моделі ціноутворення у сфері послуг / А.В. Бакурова, Д.В. Очеретін // Вісник Запорізького національного університету. - 2011. - №2 (10). - С. 105-112.

6. Быковская Е.В. Применение когнитивного моделирования при управлении предприятием / Е.В. Быковская, А.В. Иванова, Н.В. Пронина // Вестник ТГТУ. - 2008. - Т. 14. - № 2. - С. 437-441.

7. Должанський І. Алгоритм управління діяльністю промислових підприємств на основі збалансованої системи показників [Електронний ресурс] / І. Должанський, І. Ягнюк. - Режим доступу: http://www.nbuv.gov.ua/portal Soc_Gum/Skhid/2010_5/3.pdf.

8. Kosko B. Fuzzy cognitive Maps / B. Kosko // International journal of Man. - Machine Studies. - 1986. - № 24. - P. 65-75.

9. Колодізєв О.М. Формування багаторівневої системи показників фінансування інноваційної діяльності / О.М. Колодізєв // Актуальні проблеми економіки. - 2013. - №8. - С. 146-153.

10. Лагерев Д.Г. Автоматизация разработки управленческих решений в социально-экономических системах на основе применения нечетких когнитивных карт: автореф. дис...канд.. экон. наук: 05.13.10 / Д.Г. Лагерев. - Брянск. - 20 с.

11. Максимов В.И. Когнитивные технологии для поддержки принятия управленческих решений / [Электронный ресурс]. - Режим доступу: http:// //www.iis.ru/events/19981130/maxi.mov.ru.

12. Максимов В.И. Когнитивный анализ и управление развитием ситуации / В.И. Максимов // Мат. 1-й международной конференции «Когнитивный анализ и управление развитием ситуации (CASC'2001) ИПУ РАН». - Москва, 2001. - T.2. - C. 10-21

13. Паклин Н.Б. Нечетко-когнитивный подход к управлению динамическими системами / Н.Б. Паклин // Искусственный интеллект. - 2003. - №4. - С. 342-348

14. Силов В.Б. Принятие стратегических решений в нечеткой обстановке / В.Б. Силов. - Москва : ИНПРО-РЕС, 1995 $-228 \mathrm{c}$.

15. Таран Т.А., Шемаев В.Н. Метод моделирования рефрлексивного управления на основе когнитивных карт» // Tp. IV междунар. конф. «Когнитивный анализ и управление развитием ситуаций. - Москва : ИПУ РАН, 2004. - С. 132-139.

16. Шемаев В.Н. Обобщенные оценки факторов в задачах когнитивного моделирования / Т.А. Таран, В.Н. Шемаев // Математичні машини і системи. - 2004. - № 3. - С. 111-124.

17. Головінов О.М. Теоретичні основи і прикладні аспекти розвитку соціального партнерства в Україні О.М. Головінов, М.І. Головінов // Вісник економічної науки України. - 2014. - № 1. - С. 18-22.

18. Gerrard M.B. What are Public-private Partnerships, and how do they Differ from privatizations? / M.B. Gerrard // Finance\&Development. - № 38 (3). - P. 43-49.

19. Запатріна І.В. Розвиток державної підтримки публічно-приватного партнерства в Україні / І.В. Запатріна // Економіка і прогнозування. - 2011. - № 3. - С. 9-24.

20. Федулова Л.І. Фінансові аспекти державно-приватного партнерства / Л.І. Федулова // Фінанси України. - 2012. № 12. - С. 79-92

21. Шилепницький П. Характеристика ефективності державно-приватного партнерства [Електронний ресурс] П. Шилепницький // Ефрективна економіка. - 2015. - № 10. - Режим доступу: http://www.economy.nayka.com.ua/?op=1\&z=4370.

22. Остапенко В.М. Методичне забезпечення формування фінансового потенціалу публічно-приватного партнерства / B.М. Остапенко // Проблеми та перспективи розвитку державно-приватного партнерства у галузі житлово-комунального господарства : матеріали Всеукр. наук.-практ. інтернет-конф. (Харків, 1-28 лютого 2015 р.). - Харків : ХНУМГ ім. О.М. Бекетова, 2015. - С. 126-127.

23. Тищенко В.Ф. Экономические основы публично-частного партнерства / В.Ф. Тищенко // Учет и статистика. - 2012. - № 4 (28). - C.102-105. 
В.Ф. Тищенко, Н.В.Белікова, В.М. Остапенко. Когнітивне моделювання при управлінні процесами активізації публічно-приватного партнерства в Україні

1. Ukaz Prezydenta Ukrai'ny Pro strategiju stalogo rozvytku «Ukrai'na 2020» [Decree of the President of Ukraine on the strategy of sustainable development "Ukraine 2020»] (2015). zakono.rada.gov.ua. Retrieved from: http://zakon0.rada.gov.ua/laws/show/5/2015 [in Ukrainian].

2. Zakon Ukrai'ny Pro plan zakonodavchogo zabezpechennja reform v Ukrai'ni № 509-19 vid 04.06.2015 r. [The Law of Ukraine About the plan of legislative support for reform in Ukraine number 509-19 of 04.06.2015 p.] (2015). zakon5.rada.gov.ua. Retrieved from: http://zakon5.rada.gov.ua/laws/show/509-19 [in Ukrainian].

3. Postanova Verhovnoi' Rady Ukrai'ny Pro programu dijal'nosti Kabinetu Ministriv Ukrai'ny № 1099-VIII vid 19.04 .2016 [Resolution of the Verkhovna Rada of Ukraine on the program of the Cabinet of Ministers of Ukraine № 1099-VIII 19.04.2016 p] (2016). zakon3.rada.gov.ua. Retrieved from: http://zakon3.rada.gov.ua/laws/show/1099-19 [in Ukrainian].

4. Axelrod, R. (1976). The Structure of Decision: Cognitive Maps of Political Elites. Princeton: University Press

5. Bakurova, A. (2011). Ocinka systemnyh harakterystyk kognityvnoi' modeli cinoutvorennja u sferi poslug [Evaluation of cognitive performance system pricing in services]. Journal of Zaporizhzhya National University, 2 (10), 105-112 [in Ukrainian].

6. Bykovskaya, E. (2008). Prymenenye kognytyvnogo modelyrovanyja pry upravlenyy predpryjatyem [Application of Cognitive modeling in the operation of business]. THTU Journal, 2, 437-441 [in Russian].

7. Dolzhanskiy, I. (2010). Algorytm upravlinnja dijal'nistju promyslovyh pidpryjemstv na osnovi zbalansovanoi' systemy pokaznykiv [The algorithm of management of the industry based on the Balanced Scorecard]. nbuv.gov.ua. Retrieved from: http://www.nbuv.gov.ua/portal/ Soc Gum/Skhid/2010 5/3.pdf [in Russian]

8. Kosko, B. (1986). Fuzzy cognitive Maps. International Journal of Man, 24, 65-75

9. Kolodiziev, O.M. (2013). Formuvannja bagatorivnevoi' systemy pokaznykiv finansuvannja innovacijnoi' dijal'nosti [Formation of multilevel system of indices on innovative activity financing]. Actual Problems of Economics, 8, 146-153 [in Ukrainian].

10. Lagerev, D. (2007). Avtomatyzacyja razrabotky upravlencheskyh reshenyj $v$ socyal'no-ekonomycheskyh systemah na osnove prymenenyja nechetkyh kognytyvnyh kart [Automation of administrative decisions in the social and economic systems based on the application of fuzzy cognitive maps]. Extended abstract of candidate's thesis. Bryansk [in Russian]

11. Maksimov, V. (2001). Kognytyvnyj analyz y upravlenye razvytyem sytuacyy [Cognitive analysis in management of the situation]. 1st International Conference Cognitive analysis and management of the situation (CASC'2001) ICS RAS, 2, 10-21 [in Russian].

12. Maksimov, V. (2005). Kognytyvnye tehnologyy dlja podderzhky prynjatyja upravlencheskyh reshenyj [Cognitive technologies to support management decision-making]. iis.ru. Retrieved from: // //www.iis.ru/events/19981130/maxi.mov.ru [in Russian].

13. Paklin, N. (2003). Nechetko-kognytyvnyj podhod k upravlenyju dynamycheskymy systemamy [Fuzzy cognitive approach to managing dynamic systems]. Artificial Intelligence, 4, 342-348 [in Russian].

14. Silov, V. (1995). Prynjatye strategycheskyh reshenyj v nechetkoj obstanovke [The adoption of strategic decisions in fuzzy environment]. Moscow: INPRO-RES [in Russian].

15. Taran, T., \& Shemaev, V. (2004). Obobshhennye ocenky faktorov v zadachah kognytyvnogo modelyrovanyja [Generalized assessment factors in cognitive modelling tasks]. Mathematical Machines and Systems, 111-124 [in Russian].

16. Taran, T., \& Shemaev, V. (2004). Metod modelyrovanyja refleksyvnogo upravlenyja na osnove kognytyvnyh kart [Reflexive control simulation method based on cognitive maps]. Cognitive analysis and development management situations, 19 , 132-139 [in Russian].

17. Golovinov, A.M., \& Golovinov, M.I. (2014). Teoretychni osnovy i prykladni aspekty rozvytku social"nogo partnerstva v Ukrai'ni [Theoretical basis and applied aspects of social partnership in Ukraine] Journal of Ukrainian economics, 1, 18-22 [in Ukrainian].

18. Gerrard, M.B. (2001). What are Public-private Partnerships, and how do they Differ from privatizations? Finance\&Development, 38 (3), 43-49.

19. Zapatrina, I.V. (2011). Rozvytok derzhavnoi' pidtrymky publichno-pryvatnogo partnerstva v Ukrai'ni [Development of state support for public-private partnership in Ukraine] Economics and Forecasting, 3, 9-24 [in Ukrainian].

20. Fedulova, L.I. (2012). Finansovi aspekty PPP [Financial aspects PPP]. Finance of Ukraine, 12, 79 - 92 [in Ukrainian]

21. Shylepnytskyi, P. (2015). Harakterystyka efektyvnosti derzhavno-pryvatnogo partnerstva [Characteristics of public-private partnership's effectiveness]. Effective economics. Retrieved from: http://www.economy.nayka.com.ua/pdf/10_2015/8.pdf [in Ukrainian].

22. Ostapenko, V.M. (2015). Metodychne zabezpechennja formuvannja finansovogo potencialu publichno-pryvatnogo partnerstva [Supportive financial potential formation of public-private partnership]. Problems and prospects of development of public-private partnership in the field of Housing: All-Ukrainian. nauk. and practical. Internet conference. (Kharkiv, 1-28 February 2015). Kharkiv: Beketov HNUMH, 126-127 [in Ukrainian].

23. Tyscenko, V.F. (2012). Ekonomicheskie osnovy publichno-chastnogo partnerstva: vozmozhnosti i perspektivy razvytija [Economic Principles of public Partnership: Opportunities and prospects of development]. Accounting and Statistics, 4 (28), 57-63 [in Russian].

В.Ф. Тищенко, д-р екон. наук, доцент, старший науковий співробітник, НДЦ ІПР НАН України (м. Харків, Україна);

H.B. Белікова, д-р екон. наук, доцент, вчений секретар, НДЦ ІПР НАН України (м. Харків, Україна);

B.M. Остапенко, канд. екон. наук, викладач кафедри управління фінансовими послугами, Харківський національний економічний університет імені Семена Кузнеця (м. Харків, Україна)

Когнітивне моделювання при управлінні процесами активізації публічно-приватного партнерства в Україні 
у статті викладено авторський погляд на застосування когнітивного моделювання при управлінні процесами активізації публічно-приватного партнерства (ППП) в регіонах України. Авторами проаналізовано фрактори позитивного та негативного впливу на активізацію ППП з боку публічного та приватного партнерів, які чинять позитивний чи негативний вплив на активізацію ППП (цільовий концепт «Інвестиції»). 3 метою дослідження причиннонаслідкових зв'язки між факторами запропоновано використання когнітивних карт. Розроблено когнітивну модель впливу множини концептів на цільовий концепт «Інвестиції» та здійснено їі статичний аналіз (виявлено концепти, які здійснюють найбільший дисонанс системи).

Ключові слова: публічно-приватне партнерство, когнітивне моделювання, знаковий орграф, консонанс, дисонанс, економічні реформи.

B.Ф. Тищенко, д-р экон. наук, доцент, старший научный сотрудник, НИЦ ИПР НАН Украины (г. Харьков, Украина);

H.B. Беликова, д-р экон. наук, доцент, ученый секретарь, НИЦ ИПР НАН Украины (г. Харьков, Украина);

B.H. Остапенко, канд. экон. наук, преподаватель кафеедры управления финансовыми услугами, Харьковский национальный экономический университет (г. Харьков, Украина)

Когнитивное моделирование при управлении процессами активизации публично-частного партнерства в Украине

В статье изложен авторский взгляд на применение когнитивного моделирования при управлении процессами активизации государственно-частного партнерства (ППП) в регионах Украины Авторами проанализированы факторы положительного и отрицательного влияния на активизацию ППП со стороны публичного и частного партнеров, оказывающих положительное или отрицательное влияние на активизацию ППП (целевой концепт «Инвестиции»). С иелью исследования причинно-следственных связях между факторами предложено использование когнитивных карт. Разработан когнитивную модель влияния множества концептов на целевой концепт "Инвестиции» и осуществлена е статический анализ (выявлено концепты, которые осуществляют наибольшее диссонанс системы).

Ключевые слова: государственно-частное партнерство, когнитивное моделирование, знаковый орграф, консонанс, диссонанс, экономические реформы.

Отримано 03.02.2017 p. 